\title{
FOXP2 wt Allele
}

National Cancer Institute

\section{Source}

National Cancer Institute. FOXP2 wt Allele. NCI Thesaurus. Code C75490.

Human FOXP2 wild-type allele is located in the vicinity of $7 q 31$ and is approximately 279

$\mathrm{kb}$ in length. This allele, which encodes forkhead box protein $\mathrm{P} 2$, plays a role in

transcription during brain development. Mutations in the gene are associated with

speech-language disorder 1 and a translocation $t(5 ; 7)(q 22 ; q 31.2)$ is associated with severe speech and language impairment. 